\title{
The Market-Oriented And Integrative Management Model For Successful Internationalisation Of Vocational Education And Training Services
}

Andrea Mewaldt, Open Europe Consulting, Munich, Germany

\begin{abstract}
Export of VET services has become the rapidly growing business field within the service sector. Austria and Germany traditionally run the vocational education and training (VET) by the socalled 'Dual Apprenticeship System', the public-private co-management of employers and public vocational schools. Both countries promote VET internationalisation, and VET service providers seek for respective management strategies. This paper contributes to the question "How do VET providers successfully internationalise?"
\end{abstract}

As finding the paper presents the market-oriented and integrative management model for VET internationalisation into emerging markets. The explorative study applied the "market-oriented innovation management research method" that was chosen to highlight the paradigm shift in VET internationalisation towards market-orientation. Moreover, the method strongly involves the user's view what is is in compliance with latest value creation and value co-creation theories in service management.

Keywords: Internationalisation; Emerging Markets; Vocational Education And Training (VET); Market Orientation; Innovation Management; Multi-Stakeholder Approach; Market Entry Modes; Service Management; Value Creation; Value Co-Creation

\section{INTRODUCTION}

\section{Vocational Education and Training (VET) as Export Good}

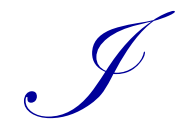

nternational companies need the best qualified personnel in target countries worldwide. Thereby, due to the internationalisation of higher education management positions comparably can be more easily staffed than blue-collar positions. MBA and other international management programmes are especially well developed. However, particularly in emerging markets too little and insufficient programmes of vocational education and training (VET) are offered in order to cover the shortage of production workers or technical professions.

VET in form of the 'Dual Apprenticeship System' (DAS) is the main concept of German speaking countries and consists of professional know-how mediation in public vocational schools and professional skills acquisition as daily training-on-the-job in the firm where the apprentice is employed. VET degrees are accredited by public authorities. In that way the 'Dual Apprenticeship System' is based on co-management of private companies and public education institutions. According to Hellwig (2006) the "German vocational education and training (VET) system and especially the dual apprenticeship system enjoy excellent reputation in the international context of VET". Therefore, German and Austrian VET might be a promising export good. 


\section{The Paradigm Shift towards Entrepreneurship and Market-Orientation}

The entrepreneurial Anglo-Saxon mind-set in education services represents the utterly new thinking against the German and Austrian non-profit orientation of VET services when vocational schools are fully subsidised by the state and apprentices' compensation is depending on the sovereignty in wage bargaining between firms and labour unions. In 2001, in Germany the Initiative for International Marketing of Vocational Education (iMOVE) was founded to push-start German VET export with the new commercial thinking. In the meantime public authorities and VET providers follow this entrepreneurial mind-set.

Also, Austrians already carefully deal with the paradigm shift to market orientation and takes the economic point of view into account: "ad definitionem" VET export is "(zumindest weitestgehend) kostendeckend" ["is (at least as far as possible) covering the costs"] (Dornmeyer \& Lenger, 2010). orientation.

The entrepreneurial paradigm shift of VET services consequently requires a turn to customer and market-

\section{Export of Education Services: The Strongly Growing Market Segment}

The German education export reached the amount of 9.4 billion euros in 2009, with 714 million euros revenues in the field of vocational education and training (VET) as the biggest share (iMOVE; Booz \& Company, 2010). "This export volume shows that education plays the significant role in the German services sector and that so far its economic impact has been underestimated. The education export outmatches the export of insurance services (2.9 billion euros), advertising and exhibition services ( 3.8 billion euros) and financial services ( 9 billion euros)" (retrieved from iMOVE webpage, 14.02.2014). Also, the Austrian ibw study points out that VET internationalisation is the very promising segment of Austrian education export (Dornmeyer \& Lenger, 2010). However, the study also describes the obvious lack on VET internationalisation. The VET exporters' presentation as part of the study shows that the segments of higher education or management trainings are far ahead of export of vocational education.

\section{How Do VET Providers Successfully Internationalise?}

Sedoglavich $(2012$, p. 453) stated that the effort to find common internationalisation patterns is turned backwards: "Past research has been motivated by generalizing findings across companies, to understand patterns in the process of internationalization. This approach ignores the distinctiveness of firms in different sectors and contexts where idiosyncratic behaviour is the norm rather than the exception."

This paper contributes to finding patterns in a very specific branch that is 'education services', even with a specific closer look to VET. The research question is: "How do VET providers successfully internationalise?" Until now this question remained without a profound and comprehensive answer. In particular this desideratum is a problem for high risk TVET investments.

In the following the underlying strategic management and marketing concepts for model development on VET internationalisation are presented.

\section{THE MULTI-STAKEHOLDER APPROACH IN EDUCATION SERVICES}

The multi-stakeholder approach is suggested as concept of market-orientation in education services. When the multi-stakeholder approach is consequently linked to market-orientation it offers market chances for non-profit and for-profit education providers alike. In terms of market activities the concept comprises cross-sector cooperation and partnerships, cross-sector sales and marketing as well as cross-sector financing.

\section{Cross-Sector Co-operation and Partnership}

The Aga Khan Foundation $(2007,8)$ promoted the new proposition of cross-sector cooperation in education services: "The key point (..) may be government commitment to education, rather than government necessarily 
doing it all. In other words: it is possible for governments to meet their public obligations (sometimes more effectively) by supporting a system of education provision that engages with a diversity of actors on the ground." The same paper cited Oxfam International defining 'diversity' as "range from civil society organizations such as NGOs, churches, mosques, and community organizations to profit-making companies, and in size from individual street traders to multinational corporations" (Aga Khan Foundation, 2007, 5).

In particular, the interaction between the societal sectors seems to be important. This is supported by Mewaldt (2010) and Kaufmann, Mewaldt \& Sanchez-Bengoa (2012) who found that cross-sector co-operation is one of the success factors of social entrepreneurship in CEE countries. The conceptualisation of success factors was based on three case studies including two non-profit adult education centres in Croatia and Hungary.

Literally referring to the stakeholder approach (Freeman \& Reed, 1983; Freeman 1984, 2007) in the UNESCO study "Education for all" Draxler $(2009,37)$ uses the term "multi-stakeholder partnership in education (MSPE)' defining the public sector, the business sector and the civil society as partners of education services' mediation. In a comparative table the advantages and disadvantages of these stakeholders are listed including the desired MSPE outcomes.

Moreover, the study also gives recommendations for managing MSPEs: it proposes "that the best way to anticipate and minimize the effect of problems is to make an initial investment in collecting information, planning, negotiating, and clarification of the overall process". Halfmann (2008) described the differences of organisational cultures and of public awareness towards profit and non-profit organisations. Cultural awareness for all the players involved, and awareness towards public expectations could be added. Further, the isw study (2007) on behalf of iMOVE underlined the needed respect to partners' mutual knowledge and the recognition of each other's key competences.

\section{Cross- Sector Sales \& Marketing}

The paradigm shift towards market-orientation linked with the multi-stakeholder approach for VET internationalisation opens-up the market chances in all societal sectors: Optional sales and marketing channels are (1) Business to Business (B2B): VET providers to the companies and industries; (2) Business to Non-profit Organisations (B2NPO): VET providers to the non-governmental sector; (3) Business to Customer (B2C): VET provider to individual VET apprentices; and (4) Business to Public Administration (B2PA): VET providers to governmental sector.

The suggestion is in line with Vargo \& Lush (2011) who based on the construct of a service-dominant logic proclaim a generic "actor-to-actor" (A2A) marketing approach. Under the article's headline "It's all B2B... and beyond" the authors suggest a networked, dynamic and systematic orientation towards value creation. This goes beyond Gummesson \& Polese $(2009,347)$ who based on a network theory recommended to marketing researchers: "Address B2B, B2C/C2B and $\mathrm{C} 2 \mathrm{C}$ as aspects of an integrated marketing context." And also, Kotler \& Kellner $(2012,9)$ take a comprehensive marketing perspective when stating: "key customer markets in the 21 st century (are): consumer, business, global, and non-profit."

Taking into account these manifold marketing opportunities for education services the isw study (2007) gives emphasis to VET providers' definition of the clear unique selling proposition (USP). And, despite obvious market chances, Kotler and Kellner (2012) raise concern over the lower pricing strategies in non-profit markets that as a consequence may negatively affect the quality of products or service.

\section{Funding Opportunities}

Besides market opportunities through sales and marketing across-the sectors the multi-stakeholder approach additionally allows fundraising from private foundations or public administration. Possible funds could be various kinds of subsidies raised either in the domestic market either in the foreign market. Dornmeyer \& Lenger (2010) in particular support public funding during the initial and market entry phases of VET internationalisation because VET export needs a lot of resources and time. The study suggests initial funding, soft loans, grants for 
marketing, research funds as well as financial guarantees for initial VET internationalisation projects which finally leave the investment risk with a minimum of $20 \%$ to the VET providers. Interview partners of the following research also stressed that additional fundraising is also a supportive option to accelerate the market development in the foreign market.

Subsequently, VET providers could include the suitable cross-sector fundraising strategy into their business cases. Hereby, they should select the potential funding organisations very carefully. Anyway, fundraising should be in line with the VET providers legal form and the own positioning as non-profit or for-profit organisation in the respective market. As well, fundraising should be adjusted to specific target groups taking part in the educational programmes.

\section{INTERNATIONALISATION STRATEGIES}

\section{The Uppsala Process Model and Market Entry Modes}

Based on the internationalisation study of Swedish manufacturers the Uppsala Process Model (U-Model) suggested by Johanson \& Wiedersheim-Paul (1975) comprises four sequent internationalisation stages of the 'establishment chain' each giving input to the following one. The four stages start with 1./ no regular export; then developing 2./ export via independent representatives (agent); and going on with 3./ establishing the sales subsidiary; and finally 4./ being fully committed by establishing the production and by manufacturing in the foreign markets.

According to the authors the process overcomes two important obstacles of internationalisation which are the lack of knowledge and resources, and, it comes along with incremental decision making. Johanson \& Vahlne $(1977,26)$ understand the U-model as cumulative learning process of increasing market knowledge, and correspondently increasing the amount of commitment, defined as the amount of resources committed. "The more specific resources are invested needs the higher is the degree of commitment". Incremental learning might be the advantage to be better safeguarded against bankruptcy in the internationalisation (Forsgren \& Hagström, 2007).

Johanson \& Vahlne (1977) introduced the concept of psychic distance. The authors recommended to starting the internationalisation into close countries because psychic distance is declining with gaining market knowledge and experience. By this way market uncertainty can be reduced. Applying the Uppsala school of internationalisation (Johanson \&Vahlne, 1977, 1990, 2006, 2009; Johanson \& Wiedermann-Paul, 1975) to VET internationalisation the several entry modes with different range of commitment have been identified. There are modes with little commitment and therefore less risk such as incoming export, pilot projects or E-learning, and others with high commitment and risks like joint ventures or foreign direct investment (FDI).

Moreover, the presentation of the market entry modes of VET internationalisation in table 1 reflects further internationalisation theories: Keuper \& Schunk (2011) distinguish between foreign market entries modes with and without capital participation. Carvusvil (1980) differentiate between reactive and pro-active modes in the internationalisation process. The researcher found that reactive activities lead to ad hoc and experimental export but pro-active exports are entrepreneurial, initial and innovation-based. The presentation also considers the critics of the process model: Forsgren's (2002) found that the U-model promotes more the reactive modes of experiential learning rather than the pro-active modes. 
Table 1: Market Entry Modes of VET Internationalisation

\begin{tabular}{|c|c|c|}
\hline \multicolumn{2}{|c|}{$\begin{array}{c}\text { No Capital Participation } \\
\text { (Reactive modes / Low risk) }\end{array}$} & $\begin{array}{c}\text { Capital Participation } \\
\text { (Pro-active modes / High risk) }\end{array}$ \\
\hline No Resource Transfer & Resource Transfer & Increase of Participation \\
\hline $\begin{array}{l}\text { Sales to Home Market Clients } \\
\text { Home market's clients purchase } \\
\text { VET services that get executed in } \\
\text { foreign markets }\end{array}$ & $\begin{array}{l}\text { Business Partners Co-operation I } \\
\text { Licensing of programmes or methods to } \\
\text { foreign VET providers }\end{array}$ & $\begin{array}{l}\text { Foreign Direct Investment I } \\
\text { Industrial VET training centres in } \\
\text { foreign markets; serving mainly needs of } \\
\text { own production sites and local branch }\end{array}$ \\
\hline $\begin{array}{l}\text { VET Service on Request } \\
\text { International tenders or pilot } \\
\text { projects }\end{array}$ & $\begin{array}{l}\text { Business Partners Co-operation II } \\
\text { Cooperation with industrial clients: } \\
\text { VET in clients' production sites and } \\
\text { training facilities in the foreign market }\end{array}$ & $\begin{array}{l}\text { Foreign Direct Investment II } \\
\text { Equity joint venture, fully-owned } \\
\text { subsidiary, merger \& acquisition }\end{array}$ \\
\hline $\begin{array}{l}\text { Incoming Export } \\
\text { Training of foreign apprentices } \\
\text { in training centres and } \\
\text { companies in home market }\end{array}$ & $\begin{array}{l}\text { Business Partners Co-operation III } \\
\text { Contractual joint ventures and } \\
\text { strategic alliances with foreign VET } \\
\text { providers; e.g. using the partners' } \\
\text { facilities and/or foreign market channels }\end{array}$ & $\begin{array}{l}\text { Add on: } \\
\text { Electronic Market Entry II } \\
\text { Localised blended learning in local } \\
\text { languages \& culturally adapted; practical } \\
\text { VET instructions in the own foreign } \\
\text { training workshop }\end{array}$ \\
\hline $\begin{array}{l}\text { Indirect Export } \\
\text { Commercial agencies or } \\
\text { distributors in the foreign markets }\end{array}$ & $\begin{array}{l}\text { Business Partners Co-operation IV } \\
\text { Franchising to foreign business partner; } \\
\text { main investments by franchisor, stronger } \\
\text { control and branding }\end{array}$ & \\
\hline $\begin{array}{l}\text { Direct Export } \\
\text { Sales from home market via e- } \\
\text { commerce, single business trips } \\
\text { and fairs or the representative } \\
\text { office in the foreign market. }\end{array}$ & & \\
\hline $\begin{array}{l}\text { Electronic Market Entry I } \\
\text { CBT/WBT: E-learning or } \\
\text { blended learning in German or } \\
\text { English, e.g. combined with } \\
\text { incoming export }\end{array}$ & & \\
\hline
\end{tabular}

Source: Own Source: Referring to Johanson \& Wiedermann-Paul (1975), Johanson \&Vahlne (1977, 1990, 2006, 2009); Carvusvil (1980); iMOVE, Sachse, U. (2008); Keuper \& Schunk (2011)

\section{Born-global Companies and Timing Strategies}

Nowadays many service companies are classified as born-global. Born-global companies are companies that already early after start-up go global. Technology and globalised infrastructure support born-global firms to quickly enter several markets. Most of born global enterprises are flexible to enough to meet customer expectations and they tend to find market niches (Knight 2004). This in particular concerns VET internationalisation.

Moen $(2002,2004)$ described the born-global companies as the 'new generation of European exporters' which in particular are the small and medium-sized enterprises. This is remarkable because most VET providers belong to the group of SMEs. The gradual development process described in the internationalization process models was not found evident. Newly established born-global companies are similar to old global companies with regard to 'competitive advantage', 'export strategy', 'international orientation' and 'market situation'. The international orientation of decision makers seem to be import factors to explain the difference of born-global firms and newly established locals (Moen. 2002).

Due to large market opportunities born-global companies grow faster as high-growth domestic companies (Keen \& Etemad, 2012). Freeman S. et al. (2013) stated that born global companies are strongly affected by "periods of global economic decline or changing competitive conditions". The authors developed the strategic model for born-global firms "moving between outward and inward-oriented activity as they de-internationalize and reinternationalize". 
The first-mover advantage (Spence, 1981, Lieberman, 1987 Lieberman \& Montgomery, 1988) is strongly linked with the incremental learning in the internationalisation process (Johanson \&Vahlne, 1977). Nakata, \& Sivakumar, (1997) analysed the first-mover advantage regarding commitment in emerging markets. As practical implications of the results the authors suggested to marketing practitioners accompanying the pioneering strategy in an emerging market by an understanding of the market's economic, technological, socio-cultural, legal/political, and competitive/marketing conditions. This insight is supported by latest literature: Malik $(2012,662 \mathrm{f})$ proposed that "the first-movers tend to have better knowledge and greater commitments to the local market". Regarding emerging markets on the example of China the author proposed that the first-mover advantage "plays a significant role in the deflecting environmental uncertainty through international business alliance". Other late articles deal with the market volatility in emerging markets. Cleff \& Rennings (2011) found that in the internationalisation of environmental innovation the success of a timing strategy depends on country-specific lead market potentials, on market and technology characteristics and on the regime of the country-specific regulation.

\section{Eclectic Models on VET internationalisation}

Beyond the definition of market entry modes the eclectic theory (Dunnings 1980, 1988, 1995) is suggested to be applied for model development of VET internationalisation. Goodnow (1986) presented overall 140 variables as internal and external success factors for internationalisation. Several authors, e.g. Johanson \& Vahlne (1990); Knight (1999) and O'Farrell et al. (1998) required the specific frameworks for internationalisation of services. The authors supported the transfer of eclectic theories to the internationalisation of services with emphasis on the resource based approaches and view to managerial attitudes. In the field of higher education Jiang \& Carpenter (2011) stated that there is a gap between models of commercial internationalisation and internationalisation of higher education. The authors presented the 'Market Entry Dynamic Framework' aiming to fills the gap 'between the modes of entry that institutions adopt to enter international markets and the ways of implementation of these market entry strategies in terms of programme delivery" (Jiang \& Carpenter, 2011, 141). The development of success strategies of VET internationalisation (Mewaldt, 2013) are based on an eclectic theory approach.

\section{CUSTOMER PERSPECTIVE IN SERVICE MANAGEMENT}

Regarding manufacturing industries Porter's value chain (1985) represents the traditional understanding of the firms' value creation. The implicit good-dominant logic was applied to value chains of products and services alike. But, already in 1990 Grönroos emphasises the specifics of the service sector. Aiming to reach competitive advantage he suggested a specific service management that differs from general management. Since the introduction of the service-dominant logic (SDL) (Lusch \&Vargo 2004; Vargo \& Lusch 2004; Vargo et al., 2008; and Vargo \& Akaka, 2009) service management has been entirely changed and developed. The former provider's perspective was turned and evolved to the customer perspective. Lastly, Grönroos \& Gummerus (2014) have described the evolution in service value creation coming from the providers' sphere (resource compilation), going to the joint sphere of providers and customers (co-creation platform) and further to the customers' sphere (customer alone and customers' eco-system).

Referring to the literature review on value creation by Mustak et al. (2013) the providers' perspective on value creation comprises service marketing concepts like e.g. customer satisfaction (Yen 2005), customer loyalty (Auh et al., 2007), improvement of service quality (Bitner et al., 1997; Ennew \& Binks, 1999). However, the customer perspective seems to make the decisive difference in service marketing:

According to Grönroos \& Gummerus (2014) the turn came with the change from the value-in-exchange conception to the value-in-use conception (Vargo \& Lusch, 2004, 2008). Hereby, the customers' service experiences get incorporated to the value creation process. Going ahead with the emergence of the customers' perspective in service management the various concepts of customers' integration were discussed. Prahalad \& Ramaswamy (2004) presented the conception of value co-creation and Dong et al. (2008) of customer participation. Through interaction and involvement customers reach direct or indirect influence and make impact on parts or on the entire value creation process. Targeting the creation of a joint value (Freeman, 2008b), the customers' perspectives finally takes effects in the firm's core business functions (Grönroos, 2011). Concluding, customers are not any longer just the 
final users to whom firms in sole responsibility offer services. By construing holistic experience customers shape the utilisation of services or products (Lemke et al., 2011).

Introducing the customer-dominant logic (CDL) Heinonen et al. $(2010 ; 2013)$ see the firm as co-creators in value creation whereas the service-dominant (SDL) logic always defined the customer in the role of co-creators. Heinonen's view is shared by the perspective of service logic (SL) (Grönroos, 2011; Grönroos \& Ravald, 2011; Grönroos \& Voima, 2013). In general, process definitions of various forms of customer integration are still underdeveloped. Grönroos \& Helle (2010) suggest that firms and customers should have a reciprocal influence to one another's value creation. The research of Eichentopf et al. $(2011,660)$ "implies that scripts help customers organize and express their needs in interactive value creation. Scripts guide behavior and inform customers when to act. The power of a script depends on the customers' past experiences". Empirically the author found "that scripts have a positive influence on the overall success of the service process."

Besides relationships between firms and customers the attention should also be drawn to the relationships among various customer groups, to the social environment and service interfaces (Verhoef et al., 2009). This is supported by Grönroos (2008) describing that value creation and in particular social value creation mainly take place in the customers' private spheres where firms are not visible and have no access to. Rihova (2012) underlines the need of attentiveness to the relationships between customers with regard to social layers of customer-to customer value co-creation. Edvardsson et al. (2011) and Lush \& Webster (2011) even suggest the social-dominant logic collaborative value creation and co-creation of various stakeholder groups. Taking the system view also Vargo \& Lusch (2011) point out the two-way relation with society stakeholders and societal processes.

Based on the conception of resource integration Pinho et al. $(2013,477)$ and on the example of health sector suggest two categories of co-creation factors to enhance the outcomes of value creation for complex services with many actors: 1./ "Factors being related to better information quality like availability, accessibility, and reliability", and 2./ "Factors being related to better actor collaboration like interconnections and dependencies".

Coming back to the multi-stakeholder approach and linking it to service management theories and VET internationalisation, the service logic, the systemic view and the social-dominant logic have to be taken into account for model development. Referring to the stakeholder approach Vauterin et al. $(2012,290)$ developed in the field of higher education (HE) developed the "model of the boundary-spanning functions in university-industry partnership". Concluding, the authors call for more research of value creation in the partnering practice.

\section{MODEL DEVELOPMENT ON VET INTERNATIONALISATION BY THE "MARKET-ORIENTED INNOVATION MANAGEMENT" RESEARCH METHOD}

\section{Well-grounded Selection of Methodology}

The model definition of the Market-oriented and Integrative Management Model of VET internationalisation is developed by the "Market-Oriented Innovation Management" research method (Kellner 2007). Targeted users of the model on VET internationalisation are direct beneficiaries of the VET model on internationalisation. These are VET providers, industries and their suppliers which most often are international SMEs, local public education institutions as well as the local VET trainers and the apprentices themselves.

Firstly, the research method is chosen to highlight the entrepreneurial paradigm shift. The research method highly complies with market- and customer orientation. The method steps shown in table 3 include the "enquiry about the requirements of the respective users" and the "single embedded case study" of a VET provider. By its proceeding the chosen research method satisfies the requirements of the customer perspective and the stakeholder approach, and of value creation and co-creation with a systemic view on an innovation development in the field of international service management.

Secondly, the research method is chosen due to its explorative approach with a strong link to innovation management theories. As VET internationalisation is an extraordinarily new theme in scientific research the path of innovation management seems to be the right track. The empirical study of Atuahene-Gima $(1999,93)$ supports the 
choice of this specific innovation management research method: Involving manufacturers and service companies "indicate(s) that market orientation has significant relationships with innovation characteristics such as innovationmarketing fit, product advantage, and interfunctional teamwork but not with product newness and innovationtechnology fit". The confirmed items are assumed to be the relevant ones for the model development because VET internationalisation is mainly an international transfer of already existing know-how, and the innovation is how the transfer into emerging markets should successfully take place.

Aiming at competitive advantage Lerro et al. (2014) presents a conceptual framework of "relationships between IC (intellectual capital) management, innovation, performance improvement, and value creation capacity". Since VET can be understood as intellectual capital the presented IC framework - even yet without empirical corroboration - may support both directions: the choice of the innovation management and the direction of marketand customer orientation, value creation and co-creation.

\section{Proceeding of Model Development}

The suggested model on VET internationalisation was developed by the following steps of the applied market-oriented innovation management research method (see table 2):

1.) Definition of the specific innovation

2.) Description of characteristics gained from various fields of knowledge and reflected experience

3.) Enquiry about the requirements of the respective users

4.) Definition of the model's structure (success strategies in the three stages of VET internationalisation)

5.) Innovation's test with view to the required features

6.) Critical reflection of the innovation to improve future operations. 
Table 2: Research Design: The Applied "Market-Oriented Innovation Management Research Method"

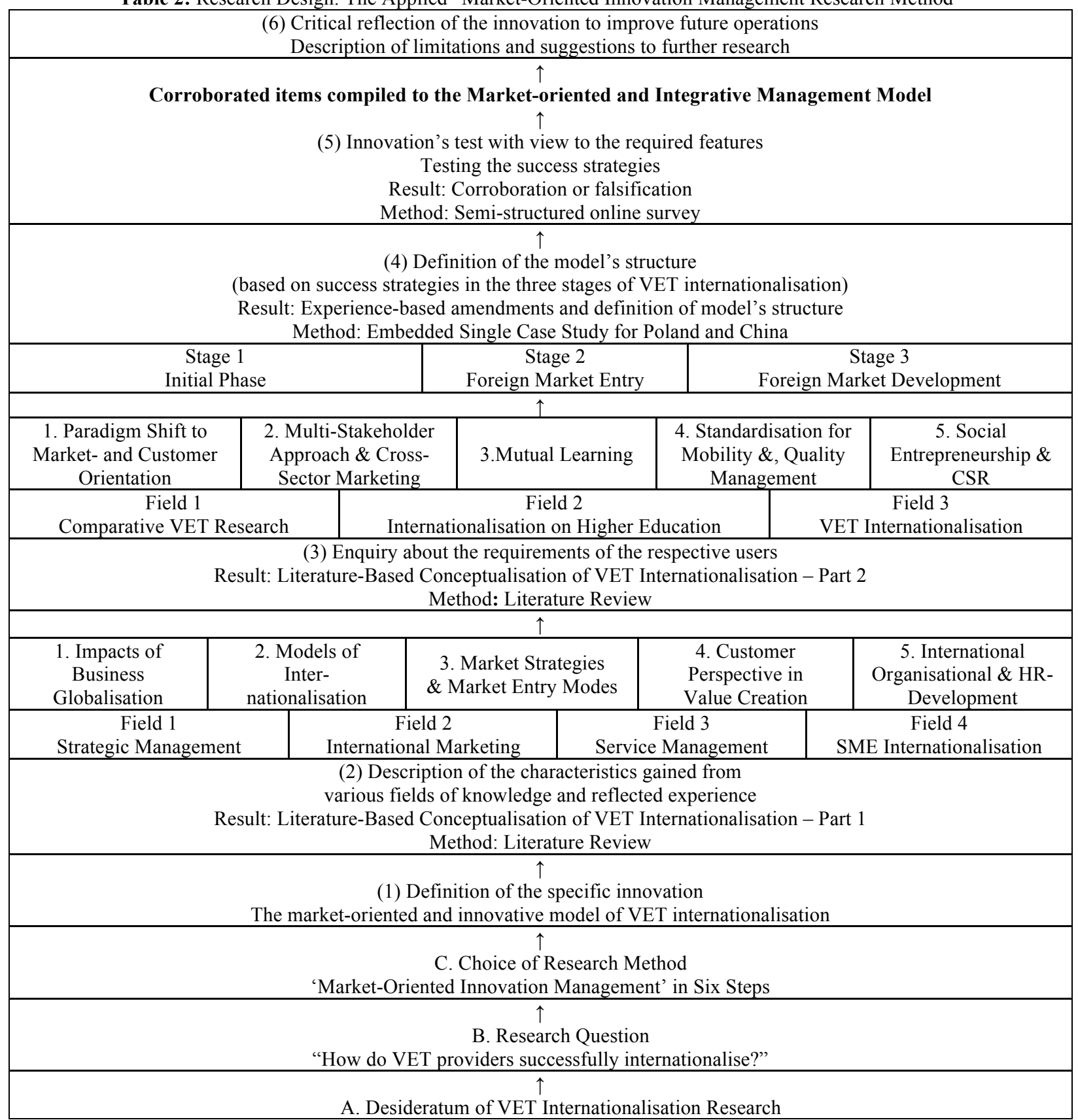

Source: Own source referring to Kellner 2007, p.41; revised version from Mewaldt (2013)

The model is developed for the three phases of VET internationalisation: The initial phase of VET internationalisation; the market entry phase; and the market development phase. 
The conceptualisation of VET internationalisation is the result of a literature review of about 500 sources:

- $\quad$ Three VET knowledge fields to define VET users' requirements: a./ Comparative VET research; b./ Internationalisation on higher education; c./ VET internationalisation; and

- $\quad$ Four management fields to describe the characteristics of internationalisation: d./ Strategic management; e./ International marketing; f./ Internationalisation of services/ service management; g./ SME Internationalisation (because VET providers are mainly small and medium enterprises).

The conceptualisation was utilised as a grounded theory of the afterwards conducted embedded single case study of VET internationalisation from Germany to China and Poland representing countries with high and low psychic distance (Johanson, \& Wiederheim-Paul, 1975).

In summary, 11 potential success strategies consisting of overall 47 implementation measures for all three internationalisation phases had been defined (Mewaldt, 2013).

In the next research step the potential success strategies and implementation measures were tested by a semi-structured online survey. By the structural equation model 11 strategies including 47 items got evaluated with regard to economic success ( $\mathrm{ROI} \geq 0)$ and towards sustainability ( $\geq 5$ years operation in the foreign market).

As VET internationalisation in German speaking markets is rather new, it is currently not possible to find the sufficient population with respective expertise that also covers the market entry and development phase over a period of five years. Thus, twenty highly experienced German and Austrian VET experts or managers of VET providers were carefully selected. Eight participants responded. Among them one finds the iMOVE experts and other experts having the most complete overview and insights in the field of VET internationalisation in Germany. Six participants answered to all three phases evaluating all 47 items by the Likert scale from 1-5 (1- no importance to the success VET internationalisation; and 5 - very high importance to the success VET internationalisation). One participant answered to the initial and foreign market entry phases and another only to the initial phase of VET internationalisation. All respondents evaluated every item twice: at first with view to the economic success, and afterwards taking into accounts the sustainability of the foreign market entry. Summarizing, they gave written comments to each of the defined success strategies.

Finally, the market-oriented and integrative management model on VET internationalisation was composed by comprising structures, activities and behaviour on the normative, strategic and operational levels (Bleicher, 1999) for all three internationalisation stages. The critical reflection of the model finalised the research.

\section{TEST RESULTS AND SUGGESTION OF THE MARKET-ORIENTED AND INTEGRATIVE MANAGEMENT MODEL ON VET INTERNATIONALISATION}

The model comprises the corroborated implementation measures of VET internationalisation that have been evaluated with a median $\geq 4$ in the normative and strategic levels in at least one of the both success criteria, and with a median $\geq 3$ in the operational level. The difference of acceptance was made because respondents evaluated the normative and strategic levels being basically more important whereas it was stated that the operational level becomes less important as soon as the activities once have been implemented. Table 3 highlights the implementation measures with best evaluation as outstanding main success factors of VET internationalisation $\left(\mathrm{m}_{\mathrm{s}}=\right.$ median of sustainability; $\mathrm{m}_{\mathrm{p}}=$ median of profitability) 
Table 3: Main Success Factors of VET Internationalisation

\begin{tabular}{|c|c|c|}
\hline MAIN SUCCESS FACTORS & $\mathbf{m}_{\mathrm{s}}$ & $\mathbf{m}_{\mathrm{p}}$ \\
\hline \multicolumn{3}{|l|}{ 1. INITIAL PHASE } \\
\hline Well-developed VET services \& success in the home market & 4 & $4 / 5$ \\
\hline Mind-set of international entrepreneurship & 4 & 5 \\
\hline Focus turned to international customers & $4 / 5$ & $4 / 5$ \\
\hline Openness to international co-operation & $4 / 5$ & $3 / 4$ \\
\hline Willingness to mutual learning & $4 / 5$ & 3 \\
\hline \multicolumn{3}{|l|}{ 2. FOREIGN MARKET ENTRY } \\
\hline Transformational leadership and communication & 5 & 5 \\
\hline Establishment of VET facilities and office in the foreign market & 5 & 5 \\
\hline Training of local managers and staff & 5 & 4 \\
\hline \multicolumn{3}{|l|}{ 3. FOREIGN MARKET DEVELOPMENT } \\
\hline Focus on change management $\&$ self-concept as a learning organisation & $4 / 5$ & $4 / 5$ \\
\hline Quality management of VET services (content, methods \& didactics) & 4 & $4 / 5$ \\
\hline Local VET accreditation (including service processes) & $4 / 5$ & $4 / 5$ \\
\hline Local branding & 5 & 4 \\
\hline
\end{tabular}

Source: Own source

In the initial phase of VET internationalisation the paradigm shift toward market-and customer orientation is highly supported. International managerial behaviour and entrepreneurial mind-set seem to be the basic elements to the entire successful internationalisation process. The well-developed home market is considered as a prerequisite to internationalisation. Thus, VET providers are no born-global companies. The willingness to mutual learning is underlined as an idiosyncratic management behaviour that once again gets supported in the foreign market development phase: then, the chance management and the self-concept as a learning organisation is evaluated being crucial for profitability and sustainability in the market.

Even when being careful with determining statements due to the small research population, nevertheless it is a remarkable discovery that the strategic planning of the internationalisation, e. g. through market analysis and decision making about target markets and entry modes, stand back behind behavioural success factors.

In the foreign market entry phase this trend is continued: the transformational leadership reaches highest scores. Further, the results emphasise to establish the own VET facility and to train the own staff. It seems there is hardly an alternative to such venture. Both success factors promote the integration into local networks and strengthen the stakeholder relation. And, both success factors enhance the cultural adaption. Thus, market volatility and uncertainty can be directly encountered based on local first-hand information and with appropriate local strategies.

VET internationalisation goes beyond export of existing know-how. In the market development phase the local branding and the further development of VET programmes by quality management and local accreditations are considered most important. Anyway, the local autonomy, as a suggested factor, was not seen the same way indispensable. German and Austrian VET providers do not want to lose control. Local branding promotes the overall market development and is assumed to be more easy for first-movers.

In the figures 1-3 the "Market-oriented and Integrative Model of VET internationalisation", including all corroborated implementation measures is presented. 


\section{Initial Phase of VET Internationalisation}

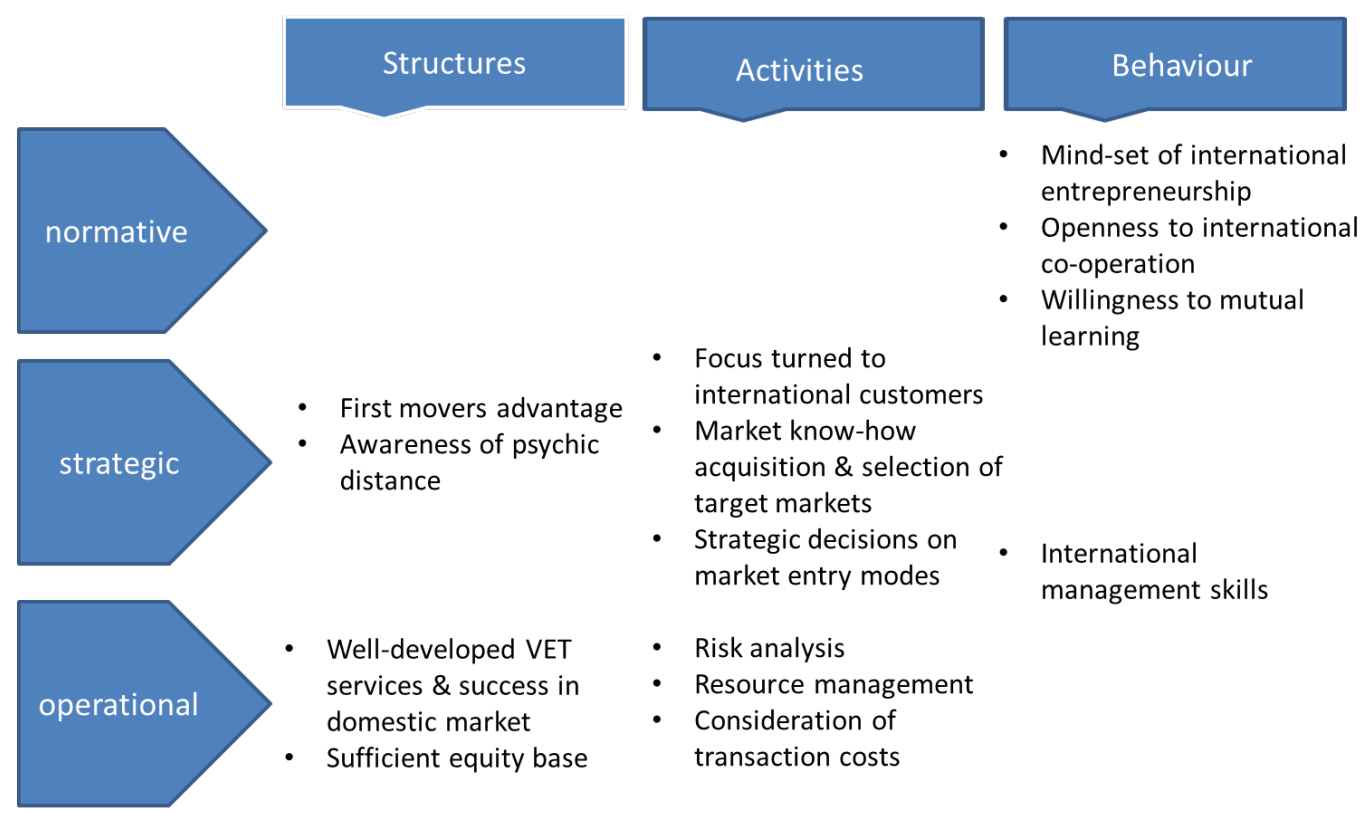

Source: Own Source based on Bleicher, K $(1999,88)$

Figure 1: The Market-oriented and Integrative Model on VET Internationalisation (I.)

\section{Foreign Market Entry Phase}

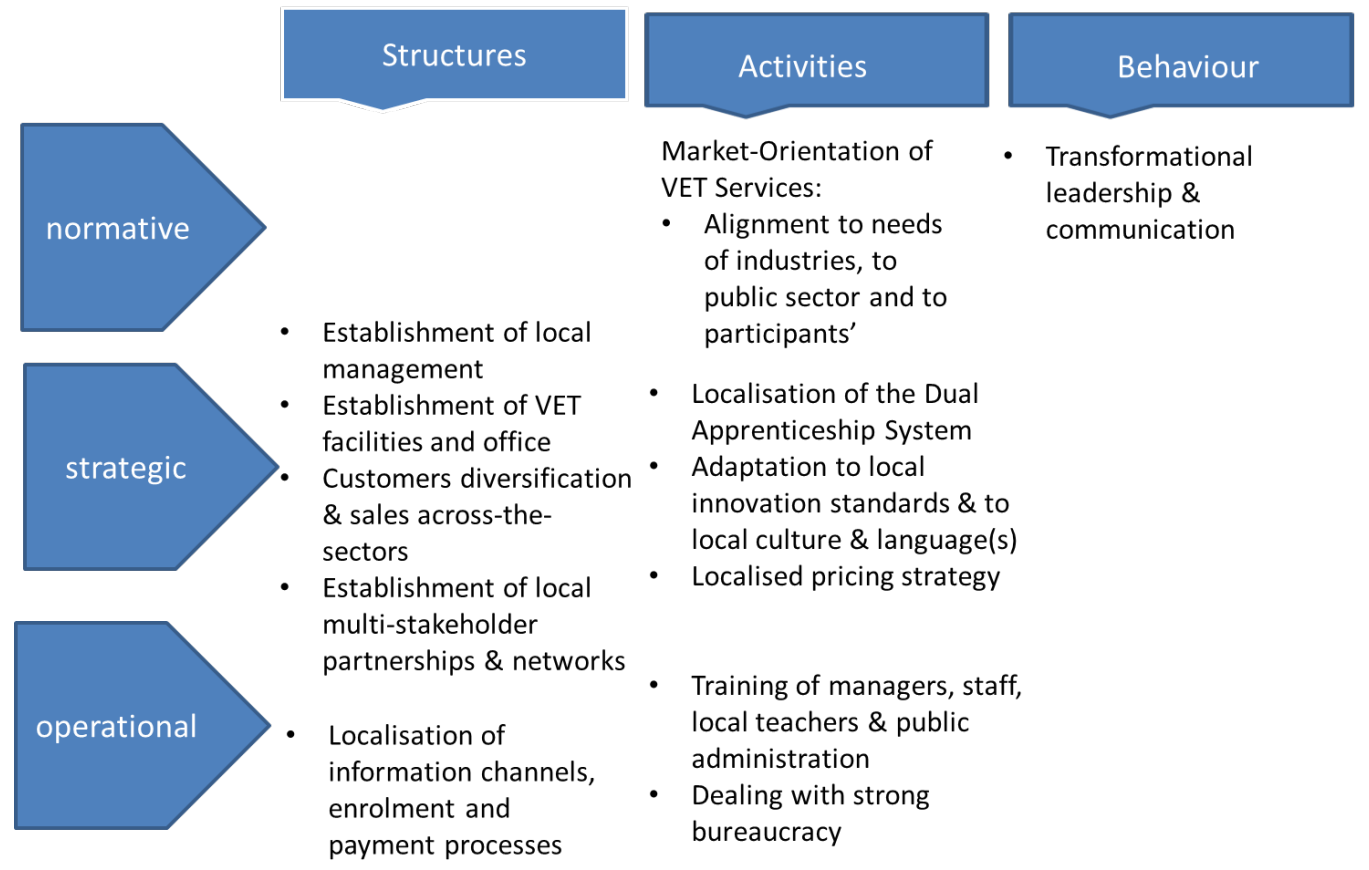

Source: Own Source based on Bleicher, K. $(1999,88)$

Figure 2: The Market-oriented and Integrative Model on VET Internationalisation (II.) 


\section{Foreign Market Development Phase}

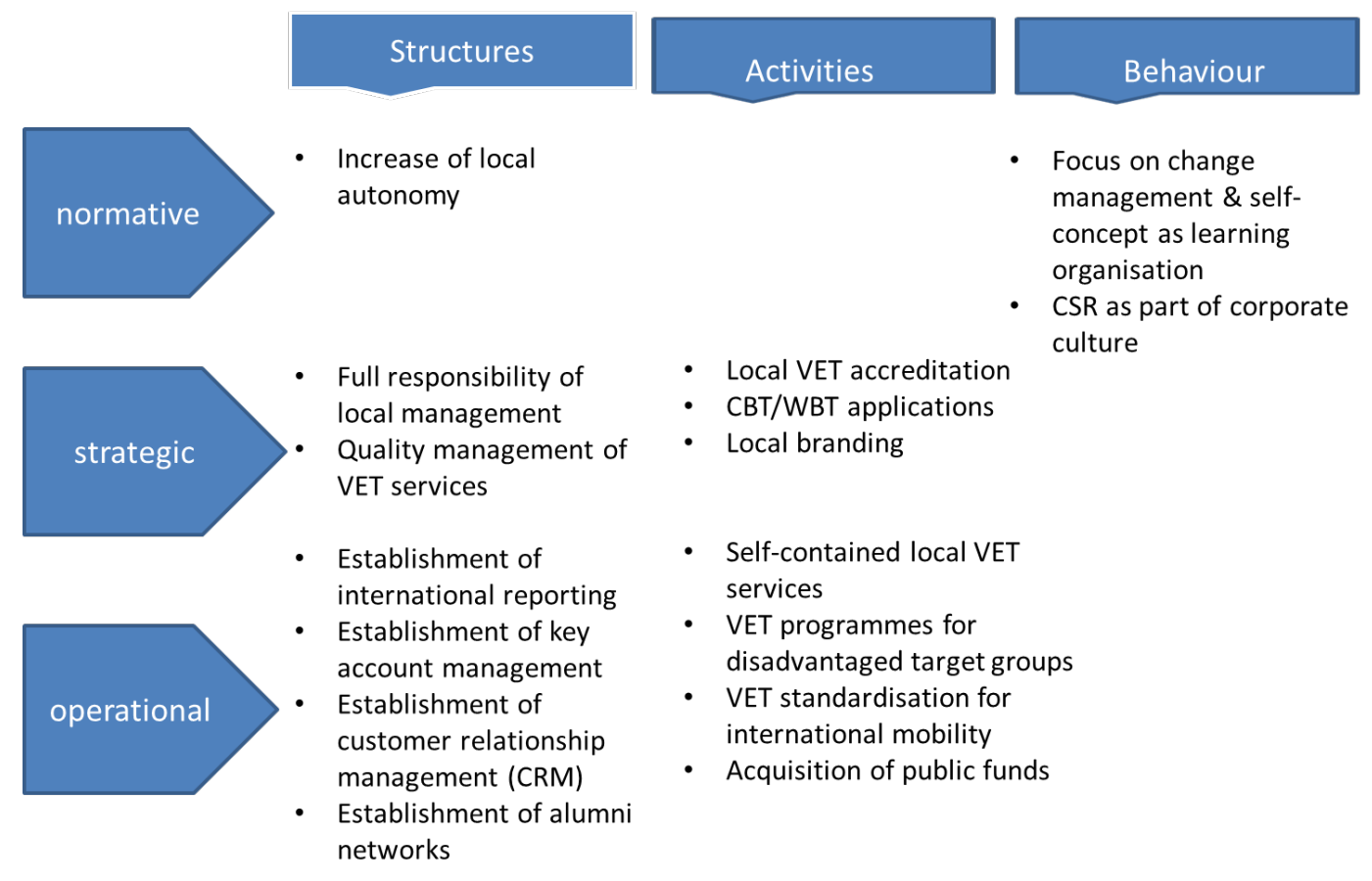

Source: Own Source based on Bleicher, K. $(1999,88)$

Figure 3: The Market-oriented and Integrative Model on VET internationalisation (III.)

\section{RESEARCH LIMITATIONS AND FURTHER RESEARCH DIRECTIONS}

The test of success strategies was limited due to little field experience in VET internationalisation. But the eight test participants insured high quality regarding practical experience in emerging markets, and considering the three internationalisation stages. The empirical test with the sufficient size of population has to be left to further research. The market-oriented and integrative model later on should be complemented by the research of systemic feedback loops in cybernetic models by Beer $(1981,1984)$; Malik $(1984,2005)$ and applied by Rempfer $(2005)$ to TVET internationalisation in a research of TVET export to Bulgaria.

With regard to Sedoglavich (2012) the market-oriented and integrative model on VET internationalisation should be also shaped in more details to VET export in specific branches like automotive, chemistry, construction etc. The German public research tender with deadline End of June 2014 is dedicated to this approach.

The effectiveness of VET programmes in emerging markets is suggested as a field of further research. Firstly, it is suggested applying the comprehensive approach about controlling of management education by Billing \& Stadelmann (2006) to VET internationalisation. Secondly, further research could widen the perspective to interdisciplinarily exploring the macro-economic and social impacts of VET education in emerging markets. Even this aspect should be part of the comprehensive VET controlling system. The investigation on macro-economic and societal impacts may or may not support Nilson $(2010,267)$ who stated: "VET is crucial to social inclusion and possibly also to economic growth". This statement is in accordance to Blunch \& Castro (2007) who especially point out the same idea in the context of developing countries. Last but not least, Goher $(2011,18)$ described by the example of Pakistan "the critical link between the status of women in society, (...) and a nation's economic growth". In this respect the gender aspect of female participation in VET and labour force in emerging markets is suggested for further research. 


\section{CONCLUSIONS AND PRACTICAL IMPLICATIONS}

The model supports the national promotion of VET export in Germany and Austria. It shows that the Dual Apprenticeship System has to be adapted to local markets. The model is intended to support various users' groups but mainly VET providers. Its consequent market- and customer orientation towards various target groups and the break-even criterion open-up the chance to bridge the gap of non-profit and for-profit orientation in VET internationalisation. Provision is made for encouraging and accelerating VET export into emerging markets. Diminishing the shortage of blue collar workers in emerging markets most probably has further economic and societal impacts. It is assumed that less developed countries being ready to offer local VET services should attract more foreign direct investments. Last but not least, VET export into emerging markets should have a positive effect towards a higher level of education, towards better incomes and towards an increase of the gross domestic product (GDP).

\section{AUTHOR INFORMATION}

Andrea Mewaldt is CEO of Open Europe Consulting positioned in the fields of international management, corporate social responsibility, vocational education and training, social entrepreneurship and civil society development. She possesses a Diploma of Social Pedagogics of the University of Applied Sciences Munich and a MBA degree for Management and Marketing in Central and Eastern Europe of the European University Viadrina, Frankfurt (Oder) / Collegium Polonicum. She passed the doctoral studies in Management Science (Module: Global Management and Leadership) at the University of Latvia and participated in several scientific conferences in Europe, Singapore and the USA. Currently, she finalises her dissertation. E-Mail: mewaldt@open-europeconsulting.de

\section{ACKNOWLEDGEMENTS}

This article publicises the results of the author's doctoral thesis at the University of Latvia in Riga. For scientific supervision and inspiration of the dissertation highest merit belongs to Prof. Dr. habil. Klaus Kellner at the University of Applied Sciences Augsburg. For continuous and integrated support during the entire doctoral study programme sincere gratitude goes to Prof. Dr. Baiba Savrina and to Prof. Dr. Erika Šumilo at the University of Latvia and to Prof. Dr. Josef Neuert at the University of Applied Sciences Kufstein Tirol. Last but not least many thanks are presented to all discussants like fellow students and contributors on conferences.

\section{REFERENCES}

1. Aga Khan Foundation (2007). Non-state providers and public-private-community partnerships in education - contributions towards achieving EFA: A critical review of challenges, opportunities and issues, Background Paper for EFA Global Monitoring Report.

2. Atuahene-Gima, K. (February, 1996). Market orientation and innovation. Journal of Business Research, 35(2), 93-103.

3. Auh, S., Bell, S. J., McLeod, C. S., \& Shih, E. (2007). Co-production and customer loyalty in financial services, Journal of Retailing, 83(3), 359-370.

4. Beer, S. (1981). Brain of the Firm: The Managerial Cybernetics of Organization, 2nd edition: London / New York, NY: Wiley.

5. Beer, S. (1984). The Viable System Model: Its Provenance, Development, Methodology and Pathology. 6. The Journal of the Operational Research Society, 35(1), 7-25.

7. Bitner, M. J., Faranda,W. T., Hubbert, A.R., \& Zeithaml, V.A. (1997). Customer contributions and roles in service delivery. International Journal of Service Industry Management, 8(3) 193-205.

8. Bleicher, K. (1999). Das Konzept integriertes Management: Visionen - Missionen - Programme, Frankfurt a. Main: Campus.

9. Blunch, N.-H., \& Castro, P. (2007). Enterprise-level training in developing countries: do international standards matter? International Journal of Training and Development, 11(4), 314-324.

10. Cavusgil, S. T. (November, 1980). On the internationalisation process of firms. European Research, 273281. 
11. Cleff, T., \& Rennings, K. (2012). Are there any first-mover advantages for pioneering firms? Lead market orientated business strategies for environmental innovation. European Journal of Innovation Management, 15(4), 491-513.

12. Dornmeyer, H. \& Lenger, B. (2010. Österreichischer Bildungsexport. Status-Quo Erhebung, ibwForschungsbericht Nr. 151. Wien: ibw Institut für Bildungsforschung der Wirtschaft.

13. Dong, B. (2009). The effects of customer participation in co-created service recovery. Journal of the Academy of Marketing Science, 36, 123-137.

14. Draxler, A. (2009). New Partnership on EFA. Building on Experience. Paris: International Institute for Educational Planning and World Economic Forum.

15. Dunning, J. (1980). Towards an eclectic theory of international production: some empirical tests. Journal of International Business Studies, 11(1), 9-31.

16. Dunning, J. H. (1988). The eclectic paradigm of international production: a restatement and some possible extension. Journal of International Business Studies, 18(2), 1-31.

17. Dunnings, J. H. (1995). Reappraising the eclectic paradigm in an age of alliance capitalism. Journal of International Business Studies, 26(3), 461-491.

18. Dunning, J. H. (2000). The eclectic paradigm as an envelope for economic and business theories of MNE activity. International Business Review, 9(2), 16-190.

19. Edvardsson, B., Tronvoll, B., \& Gruber, T. (2011). Expanding understanding of service exchange and value co-creation: a social construction approach, Journal of the Academy of Marketing Science, 39(2), 327-339.

20. Eichentopf, T., Kleinaltenkamp, M., \& van Stiphoutichen, J. (2011). Modelling customer process activities in interactive value creation. Journal of Service Management, 22(5), 650-663.

21. Ennew, C. T., \& Binks, M. R. (1999). Impact of participative service relationships on quality, satisfaction and retention: an exploratory study. Journal of Business Research, 46(2), 121-132.

22. Forsgren, M. (2002). The concept of learning in the Uppsala internationalization process model. A critical review. International Business Review, 11, 257-277.

23. Freeman, R. E. (1984). Strategic Management - A Stakeholder Approach. Boston, MA: Pitman.

24. Freeman, R.. E. (2007). Managing for stakeholders. Survival, reputation and success. New Haven: Yale University Press.

25. Freeman, R. E. (2008). Ending the so-called 'Friedman-Freeman debate'. In B. R. Agle, T. Donaldson, R. E. Freeman, M. C. Jensen, R. K. Mitchel \& D. J. Wood. Dialogue: Toward a superior stakeholder theory. Business Ethics Quarterly, 18(2), 153-190 on 162-166.

26. Freeman, R. E. \& Reed, D. (1983). Stakeholders and stakeholders: A new perspective on corporate governance, California Management Review, 25, 88-106.

27. Freeman, S., Deligonul, S., \& Cavusgil, T. (2013). Strategic re-structuring by born-globals using outward and inward-oriented activity. International Marketing Review, 30(2), 156-182.

28. Forsgren, M., \& Hagström, P. (2007). Ignorant and impatient internationalization? The Uppsala model and patterns of internationalization of Internet-related companies. critical perspectives on international business, 3(4), 291-305.

29. Goher, F. (2011). Female Education As A Determinant Of Economic Growth: The Case Study Of Pakistan, Contemporary Issues in Education Research, 4(11), 15-22.

30. Goodnow, J. D. (1985). Developments in international modes of entry analysis. International Marketing Review, 2(3), 17-30.

31. Grönroos, C. (1990), Service Management: A Management Focus for Service Competition. International Journal of Service Industry Management, 1(1), 6 - 14.

32. Grönroos, C. (2008). Service logic revisited: who creates value? And who co-creates? European Business Review, 20(4), $298-314$.

33. Grönroos, C., \& Helle, P. (2010). Adopting a service logic in manufacturing: Conceptual foundation and metrics for mutual value creation, Journal of Service Management, 21(5), 564-590.

34. Grönroos, C. (2011). A service perspective on business relationships: The value creation, interaction and marketing interface, Industrial Marketing Management, 40, 240-247.

35. Grönroos, C. \& Ravald, A. (2011). Service as business logic: implications for value creation and marketing, Journal of Service Management, 22(1), 5-22.

36. Grönroos, C., \& Voima, P. (2013). Critical service logic: Making sense of value creation and co-creation. Journal of the Academy of Marketing Science, 41(2), 133-150. 
37. Grönroos, C., \& Gummerus, J. (2014). The service revolution and its marketing implications: service logic vs service-dominant logic. Managing Service Quality, 24(3), 206-229.

38. Gummesson, E. \& Polese, F. (2009). B2B is not an island. Journal of Business \& Industrial Marketing, 5/6, 337-350.

39. Halfmann, A. (2008). Unternehmen als Teil der Zivilgesellschaft. Wie das Miteinander von Profit und NonProfit gelingen kann und woran es manchmal scheitert. In M. B. Schmidt (Ed.): Schriftenreihe für Wirtschafts-und Unternehmensethik, 17, 87-96.

40. Heinonen, K., Strandvik, T. \& Voima, P. (2013). Customer dominant value formation in service. European Business Review, Vol. 25(2), 104-123.

41. Heinonen, K., Strandvik, T., Mickelsson, K.J., Edvardsson, B., Sundström, E., \& Andersson, P. (2010). A customer-dominant logic of service, Journal of Service Management, 21(4), 531-548.

42. Hellwig, S. (2006). The competency debate in German VET: an analysis of current approaches. International Journal of Training Research, 4(1), 1-16.

43. iMOVE; isw (2007). Erfolgsfaktoren angelsächsischer Länder im internationalen Marketing beruflicher Bildung. Ergebnisse einer Studie des isw Institut für Strukturpolitik gGmbH. Bonn: iMOVE.

44. iMOVE, \& Sachse, U. (2008). Exportleitfaden Aus-und Weiterbildung. Bonn: iMOVE.

45. Jiang, N., \& Carpenter, V. (2011). Market entry dynamic framework for higher education internationalisation. Journal of International Education in Business, 4(2), 141-158.

46. Johanson, J., \& Vahle, J.-E., (1977). The Internationalization Process of the Firm: a Model of Knowledge Development and Increasing Foreign Market Commitments. Journal of International Business Studies, 8(1), 23-32.

47. Johanson, J., \& Vahlne, J.-E. (1990). The mechanism of internationalization. International Marketing Review, 7 (4), 11-24.

48. Johanson, J., \& Vahlne, J.-E. (2006). Commitment and opportunity development - a note on the internationalization process (IP) model. Management International Review, 46(2), 165-178.

49. Johanson, J., \& Vahlne, J.-E. (2009). The Uppsala internationalization process model revisited: From liability of foreignness to liability of outsidership. Journal of International Business Studies, 40, 14111431.

50. Johanson, J., \& Wiederheim-Paul, F. (October, 1975). The internationalisation of the Firm: Four Swedish Cases. Journal of Management Studies, 305-322.

51. Kaufmann, H. R.., Mewaldt, A., \& Sanchez-Bengoa, D. (2012). Social Entrepreneurship and Cross-Sectoral Partnerships in CEE Countries. In T. Burger-Helmchen (Ed.). Entrepreneurship - Gender, Geographies and Social Context, 55-80, Rijeka: In-Tech.

52. Keen, C., \& Eternad, H. (2012). Rapid growth and rapid internationalization: the case of smaller enterprises from Canada, Management Decision, 50(4), 569 - 590.

53. Kellner, K. (2007): Kommunale Profilierung. Ein neuer Ansatz für das Consulting in der angewandten Sozial- und Wirtschaftsgeographie, Habilitation Thesis, University of Augsburg.

54. Keuper, F., \& Schunk, H. A.(Eds.) (2011). Internationalisierung deutscher Unternehmen: Strategien, Instrumente und Konzepte für den Mittelstand. Wiesbaden: Gabler.

55. Knight, G. (1999). International services marketing: review of research 1980-1998. Journal of Services Marketing, 13(4), 347-360.

56 Kotler, P., \& Keller, K. L. (2012): Marketing Management, 14th edition. Boston et al.: Prentice Hall.

57. Lemke, F., Clark, M. \& Wilson, H. (2011). Customer experience quality: an exploration in business and consumer contexts using repertory grid technique. Journal of the Academy of Marketing Science, 39(6), 846-869.

58. Lerro, A., Linzalone, R. \& Schiuma, G. (2014). Managing intellectual capital dimensions for organizational value creation. Journal of Intellectual Capital, 15(3), 350-361.

59. Lieberman, M. B., (September-October, 1987). The Learning Curve, Diffusion, and Competitive Strategy. Strategic Management Journal, 9(5), 441-452.

60. Lieberman, M. B., \& Montgomery, D. B. (1988 Summer). First Mover Advantages. Strategic Management Journal, 9, Special Issue: Strategic Content Research, 41-58.

61. Lusch, R. F., Vargo, S. L. and Wessels, G. (2008). Toward a conceptual foundation for service science: contributions from service-dominant logic. IBM Systems Journal, 47(1), 5-14. 
62. Lusch, R.F., \& Webster, F. (2011). A stakeholder-unifying, cocreation philosophy for marketing, Journal of Macromarketing, 31(2), 129-134.

63. Malik, F. (1984). Strategie des Managements komplexer Systeme, 10th Edition, Paul Haupt: Bern/Stuttgart.

64. Malik, F. (2005). Die neue Corporate Governance: Richtiges Top Management - Wirksame Unternehmensaufsicht, 3rd Extended Edition 2008, Frankfurt: Frankfurter Allgemeine Buch.

65. Malik, T. (2012). First mover, strategic alliances and performance: context of turmoil in China. Chinese Management Studies, 6(4), 647-667.

66. Mewaldt, A. (2010). Aufbau des Zivilsektors in Transformationsländern: Lokalisierungsprozesse von Nichtregierungsorganisationen. Die Zivilgesellschaft als Beurteilungsmaßstab von Transformationsprozessen, Gruppendynamik und Organisationsberatung, 41, 235-254.

67. Mewaldt, A. (2013). Internationalisation of Vocational Education and Training (VET) - Success Factors Developed by the Market-Oriented Innovation Management Research Method. Education and Education Management. In Education and Education Management, Advances in Education Research, 28, 93-98.

68. Moen, O. (2002). The Born Globals: A new generation of small European exporters. International Marketing Review, 19(2), 156 - 175.

69. Moen, O., Gavlen, M., \& Endresen, I. (2004). Internationalization of small computer software firms: Entry forms and market selection. European Journal of Marketing, 38(9-19), 1236-1251.

70. Nakata, C., \& Sivakumar, K. (1997). Emerging market conditions and their impact on first mover advantages. An integrative review. International Marketing Review, 14(6), 461-485.

71. O' Farrell, P. N., Wood, P. A., \& Zengh, J. (1998). Regional influences on foreign market development by business service companies: elements of strategic context explanation. Regional Studies, 32(10), 31-48.

72. Piñho, N., Beirão, G. Patrício \& Fisk, R.P. (2104). Understanding value co-creation in complex services with many actors. Journal of Service Management, 25(4), 470-493.

73. Prahalad, C. K. \& Ramaswamy, V. (2004). Co-creating unique value with customers. Strategy and Leadership, 32(3), 4-9.

74. Rempfer, Rainer (2005). A cybernetic education model in technical disciplines [translation from Bulgarian Cyrillic], Doctoral Thesis, University of Sofia.

75. Rihova, J., Buhalis, D., Moital, M. \& Gouthro, M. B. (2013). Social layers of customer-to-customer value co-creation. Journal of Service Management, 24(5), 2013, 553-566.

76. Sedoglavich, V. (2012). Technological imperatives in the internationalization process. Results from a qualitative investigation of high-tech SMEs. Management Research Review, 35(5), 441-459.

77. Spence, A. M. (Spring, 1981). The Learning Curve and Competition. The Bell Journal of Economics, 12(1), 49-70

78. Stadelmann, P., \& Billing, B. (2006). Return on Management Education: Wie Weiterbildung wirksam wird, malik management zentrum st. gallen, OnlineBlatt 08/2006, 1-6. Retrieved from http://www.malikmanagement.com/de/pdf/publikationen/online-letter/malik-online-letter-return-on-managementeducation.pdf (14.08.2014).

79. Vargo, S. L., \& Akaka, M. A. (2009). Service-dominant logic as a foundation for service science: Clarifications. Service Science, 1(1), 32-41.

80. Vargo, S. L., \& Lusch R. F. (2004). Evolving to a new dominant logic for marketing. Journal of Marketing, 68, 1-17.

81. Vargo, S. L., Maglio, P. P. \& Akaka, M. A. (2008). On value and value creation: a service systems and service logic perspective. European Management Journal, 26, 145-152.

82. Vargo, S. L., \& Lusch R. F. (2011). It's all B2B... and beyond: Toward a systems perspective of the market. Industrial Marketing Management, 40, 181-187.

83. Vauterin, J. J., Linnanen, L., \& Marttila, E. (2012). Value creation in international higher education. The role of boundary spanning in university-industry collaboration. International Journal of Quality and Service Sciences, 4(3), 283-298.

84. Verhoef, P. C., Lemon, K. N., Parasuraman, A., Roggeveen, A., Tsiros, M., \& Schlesinger, L. A., (2009). Customer experience creation: Determinants, Dynamics, and Management strategies. Journal of Retailing, 85(1), 31-41.

85. Yen, H. R. (2005). An attribute-based model of quality satisfaction for internet self-service technology. Service Industries Journal, 25 (5), 641-659. 


\section{NOTES}

